\title{
Tawazon- An Intensive Lifestyle Diabetes Prevention Program: The Saudi Arabian Pilot [Corrigendum]
}

\author{
Mushcab H, Alsharif F, Nazeer A, et al. J Multidiscip \\ The authors apologize for this error.
}

Healthc. 2021;14:2767-2775.

Page 2772, second column, second paragraph, line 6, the text "4-64" should read "40-64".

\section{Publish your work in this journal}

The Journal of Multidisciplinary Healthcare is an international, peerreviewed open-access journal that aims to represent and publish research in healthcare areas delivered by practitioners of different disciplines. This includes studies and reviews conducted by multidisciplinary teams as well as research which evaluates the results or conduct of such teams or healthcare processes in general. The journal covers a very wide range of areas and welcomes submissions from practitioners at all levels, from all over the world. The manuscript management system is completely online and includes a very quick and fair peer-review system. Visit http://www.dovepress.com/testimonials. php to read real quotes from published authors. 